ORIGINAL

\title{
Further evidence to demonstrate the significance of serum appearance of anti-p53 antibody as a marker for progressive potential in invasive ductal carcinoma of the breast
}

\author{
${ }^{1}$ Tadahiro Nozoe, ${ }^{2}$ Emiko Nozoe, ${ }^{1}$ Mayuko Kono, ${ }^{1}$ Takefumi Ohga, and ${ }^{1}$ Takahiro Ezaki \\ ${ }^{1}$ Department of Surgery, Fukuoka Higashi Medical Center, Koga, Japan, ${ }^{2}$ Department of Breast Surgery, Saiseikai Fukuoka General Hospital, \\ Fukuoka, Japan
}

\begin{abstract}
Background : Serum appearance of anti-p53 antibody (p53Ab) has been reported as an indicator for progressive potential of human tumor tumors including breast cancer. But its significance in breast cancer has not been discussed fully. Methods : Relationship between serum appearance of p53Abs and representative data accounting for progressive potential in breast cancer, nuclear grade (NG), triple negative cancer, and the cumulative score based on these two data (TGS) was investigated among 129 women with invasive ductal carcinoma (IDC) of the breast, who had been treated with surgical resection. Results : There was a significant correlation between appearance of p53Abs and recurrence of the tumors $(P=0.035)$. Significant correlation of serum appearance of p53Abs with negative expression of $\mathrm{ER}(P=0.011)$, the proportion of $\mathrm{TNBC}(\mathrm{P}=0.013), \mathrm{NG}(\mathrm{P}=0.017)$, and TGS $(P=0.0005)$. Conclusions : Preoperative serum appearance of p53Abs can be correlated with pathological nuclear grade, incidence of triple negative breast cancer, and TGS. These results might demonstrate more powerful significance of serum appearance of p53Abs as an indicator of progressive potential in IDC of the breast. J. Med. Invest. 64 : 241 - 244, August, 2017
\end{abstract}

Keywords : anti-p53 antibody, nuclear grade, triple negative breast cancer, progressive potential

\section{INTRODUCTION}

Serum appearance of p53 antibodies can be appreciated as a similarly identified aspect of p53 gene mutations $(1,2)$, and its significance as an indicator of progressive potential of the tumors has been reported in some human malignant tumors including breast cancer $(2,3)$.

We also recently reported the close correlation of serum appearance of p53 antibodies with an incidence of triple negative breast cancer that is well known to be correlated with more malignant potential of the tumor causing worse outcome of the patients (2).

Moreover we have proposed a newly devised criteria based on the incidence of triple negative breast cancer and nuclear grade to predict tumor recurrence of invasive ductal carcinoma of the breast (4).

In this study, we investigated to find out a further evidence to demonstrate the significance of serum appearance of p53Ab as an indicator of progressive potential in invasive ductal carcinoma (IDC) of the breast.

\section{PATIENTS AND METHODS \\ Patients}

One hundred and twenty nine women with breast IDC, who had been treated with surgical resection between April 2008 and October 2013 in our institute, were studied in the current study. This study was approved by the institutional ethic committee of Fukuoka

Received for publication November 7, 2016 ; accepted May 15, 2017.

Address correspondence and reprint requests to Dr. Tadahiro Nozoe, Department of Surgery, Fukuoka Higashi Medical Center, 1-1-1, Chidori, Koga, 811-3195, Japan and Fax : +81-92-943-8775.
Higashi Medical Center.

\section{Pathologic investigation}

Pathological features were presented according to the general rules for clinical and pathological recording of breast cancer established by the Japanese Breast Cancer Society (5) and TNM classification of malignant tumors prescribed by the International Union Against Cancer (6).

\section{Triple negative breast cancer (TNBC)}

Expression of estrogen receptor (ER), Progesterone receptor (PgR), and human epidermal growth factor receptor 2 (HER2) were examined using an usual immunohistochemical methods and an additional FISH examination was performed to find out HER2 expression for cases with an immunohistochemical expression of HER2 $2+$. Then, tumors which are found to be absolutely negative for expression of hormone receptors (ER and PgR) and HER2 could be diagnosed as TNBC.

\section{Definition of nuclear grade}

Nuclear grade (NG) was determined as an aggregate of nuclear atypia score and mitotic count score according to the criteria was shown in Table 1 (7).

Determination of TGS (Triple negative cancer and nuclear grade 3 score)

Definition of TGS was shown in the previous report (4). In brief, patients who had both pathological characteristics of TNBC and NG 3 were allocated a TGS 2. Patients who had one of these characteristics were allocated a TGS 1 , and patients who had none were allocated a TGS0. 
Table 1. Decision of nuclear grade

Nuclear grade is decided by the sum of the nuclear atypia score and the mitotic counts score that are defined as follows.

Grade $1: 2$ or 3 points

Grade $2: 4$ points

Grade $3: 5$ or 6 points

Nuclear atypia score

Score 1 : Nuclei are relatively uniform in size and shape, and chromatin in inconspicuous.

Score 2 : Intermediate between 1 and 3

Score 3 : There is considerable variation in size and shape of nuclei and the increase and unevenness of chromatin, sometimes having giant nucleoli.

\section{Mitotic counts score}

After selecting the area in which mitoses are most abundant by small or intermediate magnification, the mitoses are counted on larger magnification. When using a $20 \mathrm{~mm}$ field of view, count 10 high-powerfields (40x objective).

Score 1: 0-4 mitoses

Score $2: 5$ - 10 mitoses

Score $3: 11$ or more than 11 mitoses

\section{Assay of serumanti-p53 antibodies}

Serum were drawn from the patients preoperatively and serum anti-p53 antibodies (p53Abs) were assessed by an enzyme-linked immunoabsorbent assay (ELISA) using anti-p53 EIA kit II (MESACUP anti-p53 test (Medical and Biological Laboratories Co., Ltd, Nagoya, Japan) (8). The samples were added to the wells of a microtiter plate coated with either wild-type human p53 or the control protein and then they were incubated for 60 minutes at $37^{\circ} \mathrm{C}$. After washing with the washing solution, goat anti-human immunoglobulin (IgG) antibody conjugated with peroxidase was added and incubated for 60 minutes at $37^{\circ} \mathrm{C}$. Next, the subtrate solution was added and incubated for 10 minutes. After adding the stop solution, light absorption was measured at the length of $450 \mathrm{~nm}$ using the photospectrometer. When the optic density was more than the lowest positive control samples, the samples were considered positive for p53Abs. Then the standard sample was diluted in various concentrations and the light absorption was measured in the same way. A calibration curve was constructed from the specific signals of the standard samples, then the level of p53Abs was measured using the calibration curve. According to the manufacture, patients with serum concentration of more than $1.30 \mathrm{U} / \mathrm{mL}$ was regarded to have a serum appearance of p53Abs.

\section{Statistical analysis}

Then, correlation of the serum appearance of p53Abs with clinicopathologic factors including TGS values were examined. Values were expressed mean \pm SEM. The Fisher's exact test and non-parametric test (Mann-Whitney U test) were used to compare the clinicopathologic data. A P value of less than 0.05 was considered significant.

\section{RESULTS}

p53Abs was detected in $11.6 \%$ (15 out of 129) of the sera of patients with breast IDC. Relationship between serum appearance of p53Abs and clinicopathologic characteristics were demon- strated in Table 2. No significant difference was observed regarding the age, menstruation, operative procedures, histologic type, size of the tumors, lymph node metastasis and the tumor stage. There was a significant correlation between appearance of p53Abs and recurrence of the tumors $(\mathrm{P}=0.035)$.

Table 2. Correlation of serum appearance of anti-p53 antibody with clinicopathological features

\begin{tabular}{lccc}
\hline & $\begin{array}{c}\text { p53Abs } \\
\text { Positive } \\
(\mathrm{n}=15)\end{array}$ & $\begin{array}{c}\text { p53Abs } \\
\text { negative } \\
(\mathrm{n}=114)\end{array}$ & P value \\
\hline Age & $59.5 \pm 17.8$ & $62.4 \pm 13.0$ & 0.424 \\
Menstruation & & & \\
$\quad$ Pre-menopausal & $5(33.3)$ & $20(17.5)$ & 0.146 \\
$\quad$ Post-menopausal & $10(66.7)$ & $94(82.5)$ & \\
Operation & & & \\
$\quad$ Conservation & $11(73.3)$ & $76(66.7)$ & 0.687 \\
$\quad$ Mastectomy & $4(26.7)$ & $38(33.3)$ & \\
Histology & & & \\
Papillo-tubular & $5(33.3)$ & $54(47.4)$ & 0.062 \\
Solid-tubular & $6(40.0)$ & $20(17.5)$ & \\
Scirrhous & $1(6.7)$ & $33(28.9)$ & \\
Others & $3(20.0)$ & $7(6.2)$ & \\
T factor & & & \\
T1 & $8(53.3)$ & $72(63.2)$ & 0.553 \\
T2 & $7(46.7)$ & $38(33.3)$ & \\
T3 & 0 & $4(3.5)$ & \\
Lymph node metastasis & & & \\
Positive & $3(20.0)$ & $28(24.6)$ & 0.802 \\
Negative & $12(80.0)$ & $86(75.4)$ & \\
Tumor stage & & & \\
I & $8(53.3)$ & $64(56.1)$ & 0.308 \\
IIA & $5(33.3)$ & $27(23.7)$ & \\
IIB & 0 & $16(14.0)$ & \\
III & $2(13.3)$ & $7(6.2)$ & \\
Tumor recurrence & & & \\
Yes & $3(20.0)$ & $6(5.3)$ & 0.035 \\
No & $12(80.0)$ & $108(94.7)$ & \\
\hline
\end{tabular}

p53Abs : anti-p53 antibody

Correlation of serum appearance of p53Abs with expression of hormonal receptor, ER and PgR, and HER2, incidence of TNBC, NG, and TGS was shown in Table 3. Significant correlation of serum appearance of p53Abs with negative expression of $\mathrm{ER}(\mathrm{P}=$ 0.011). The proportion of TNBC was significantly higher among patients with serum appearance of p53Abs $(\mathrm{P}=0.013)$. There was also a significant correlation between serum appearance of p53Abs and NG $(P=0.017)$. Moreover a significant correlation was observed between serum appearance of p53Abs and TGS $(P=0.0005)$.

\section{DISCUSSION}

The p53 protein accumulation in tumor cells can be recognized in many human tumors (9), and this accumulation of the mutational p53 can subsequently induce serum circulating anti-p53 antibodies (p53Abs) as the results of the immunological response to p53 (10). On the other hand, in a previous investigation (11), it was mentioned that while a development of p53 antibodies in sera of patients with malignant tumors is derived from the type of p53 gene mutation, p53 accumulation and/or p53 gene mutation does 
Table 3. Correlation of serum appearance of anti-p53 antibody and hormone-receptor expression, incidence of TNBC, NG, and TGS

\begin{tabular}{lccc}
\hline & $\begin{array}{c}\mathrm{p} 53 \mathrm{Abs} \\
\text { Positive } \\
(\mathrm{n}=15)\end{array}$ & $\begin{array}{c}\mathrm{p} 53 \mathrm{Abs} \\
\text { negative } \\
(\mathrm{n}=114)\end{array}$ & P value \\
\hline $\begin{array}{l}\text { ER expression } \\
\text { Positive }\end{array}$ & $\begin{array}{l}7(46.7) \\
8(53.3)\end{array}$ & $\begin{array}{l}90(78.9) \\
24(21.1)\end{array}$ & 0.011 \\
$\quad \begin{array}{l}\text { Negative } \\
\text { PgR expression }\end{array}$ & $7(46.7)$ & $76(66.7)$ & 0.129 \\
$\quad$ Positive & $8(53.3)$ & $38(33.3)$ & \\
$\quad$ Negative & & & \\
HER2 expression & $2(13.3)$ & $17(14.9)$ & 0.871 \\
$\quad$ Positive & $13(86.7)$ & $97(85.1)$ & \\
Negative & & & \\
TNBC & $9(60.0)$ & $100(87.7)$ & 0.013 \\
No & $6(40.0)$ & $14(12.3)$ & \\
Yes & & & \\
NG & $8(53.3)$ & $94(82.5)$ & 0.017 \\
1,2 & $7(46.7)$ & $20(17.5)$ & \\
3 & & & \\
TGS & $8(53.3)$ & $89(78.1)$ & 0.0005 \\
0 & $1(6.7)$ & $17(14.9)$ & \\
1 & $6(40.0)$ & $8(7.0)$ & \\
2 & & & \\
\hline
\end{tabular}

p53Abs : anti-p53 antibody

ER : estrogen receptor

PgR : progesterone receptor

HER2 : human epidermal growth factor receptor 2

TNBC : triple negative breast cancer

NG : nuclear grade
In the current study, although no significant correlation was found between serum appearance of p53Abs and such pathologic factors as incidence of lymph node metastasis and tumor size ( $\mathrm{T}$ factor), serum appearance of p53Abs was significantly correlated with NG 3, incidence of TNBC and also with TGS score. Moreover, tumor recurrence was found to be significantly higher among patients with serum appearance of p53Abs. On the other hand, no significant correlation of such pathologic factors regarding malignant potential of breast IDC as NG, TNBC, and TGS with serum elevation of such tumor markers as CEA and CA15-3 (data not shown).

TGS was constructed by two well-known prominent indicators of malignant potential of breast cancer of an incidence of triple negative cancer and nuclear grade of the tumor. And moreover the fact that TGS could be significantly correlated with serum appearance of p53Abs can compensate for the further clinical significance of serum appearance of p53Abs as an indicator of malignant potential of breast cancer.

The data regarding malignant potential of the tumor by measuring serum p53Abs can be brought about anytime while such pathologic factors as TNBC and NG would be definitively obtained at the timing of surgical treatment. Moreover one another advantage in measuring serum p53Abs is possibly to acquire the more objective and reproducible data. These might be helpful to both patients with breast IDC and physicians.

In conclusion, serum appearance of anti-p53 antibody, that can be easily measured, would be utilized to predict malignant potential of breast IDC.

\section{DISCLOSURE}

The authors declare that we have no financial interest or conflict of interest.

However, in our previous report, a significantly close correlation of serum p53Abs with an immunohistochemical p53 overexpression in the breast cancer tissues was demonstrated (2).

Proportion of serum appearance of p53Abs in patients with breast IDC in this study was found to be some $12 \%$, and this remains in the range of the values reported in the previous study showing from $9 \%$ to $22 \%(2,3,12-14)$.

Serum appearance of p53Abs has been reported to be found in patients bearing with even early stage breast cancer whereas it can not be detected in patients with benign tumor, indicating that serum appearance of p53Abs can possibly be a biological marker for an appropriate detection of breast cancer (15).

Moreover previous reports demonstrated that serum appearance of p53Abs could be indicator for progressive potential of breast cancer, including more frequent incidence for axillary lymph node metastasis and larger size of the breast tumors, more unfavorable prognosis of the patients (16), less favorable effectiveness derived from anthracycline-based chemotherapy for the tumors (17), and higher incidence of the pathological triple negative breast cancer (TNBC), that are absolutely negative for expression of hormone receptors (ER and $\mathrm{PgR}$ ) and HER2 and is known to have a more aggressive potential compared with other pathological type of breast IDC $(2,3)$.

Based on well known knowledge that pathological nuclear grade (NG) has been considered to show a cellular proliferation potential of breast cancer (18) in addition to the incidence of TNBC with more aggressive potential of breast cancer $(19,20)$, we recently suggested a cumulative scoring system (TGS) as a newly devised criteria to predict tumor recurrence and outcome of the patients with IDC by combination of NC and the incidence of TNBC with the results that TGS could classify prognosis and time to progression of the patients with breast IDC with a preferable stratification (4).

\section{REFERENCES}

1. Forslund A, Kressner U, Lindmark G, Inganäs M, Lundholm $\mathrm{K}$ : Serum anti-p53 in relation to mutations across the entire translated p53 gene in colorectal carcinomas. Int J Oncol 19 : 501-506, 2001

2. Nozoe T, Mori E, Kono M, Iguchi T, Maeda T, Matsukuma A, Ezaki T: Serum appearance of anti-p53 antibody in triple negative breast cancer. Breast Cancer $19: 11-15,2012$

3. Yamamoto S, Chishima T, Adachi S, Harada F, Toda Y, Arioka H, Hasegawa N, Kakuta Y : Serum p53 antibody in breast cancer. Cancer Biomark 14 : 203-208, 2014

4. Nozoe T, Mori E, Iguchi T, Ezaki T: New criteria to predict tumor recurrence in invasive ductal carcinoma of the breast. Int Surg $98: 283-288,2013$

5. Japanese breast cancer society : General rules for clinical and pathological recording of breast cancer. Breast Cancer 12 : S12-14, 2005

6. Sobin L, Gospodarowicz M, Wittekind C : International Union Against Cancer. TNM classification of malignant tumours, 7th ed. New York : Wiley-Blackwell, 2009. pp73-77

7. Tsuda H, Akiyama F, Kurosumi M, Sakamoto G, Watanabe T : Establishment of histological criteria for high-risk nodenegative breast carcinoma for a multi-institutional randomized clinical trial of adjuvant therapy. Japan National Surgical Adjuvant Study of Breast Cancer (NSAS-BC) Pathology Section. Jpn J Clin Oncol 28 : 486-491, 1998

8. Shimada H, Ochiai T, Nomura F. Japan p53 Antibody Research Group : Titration of serum p53 antibodies in 1,085 pa- 
tients with various types of malignant tumors : a multiinstitutional analysis by the Japan p53 Antibody Research Group. Cancer 97 : 682-689, 2003

9. Rivlin N, Brosh R, Oren M, Rotter V : Mutations in the p53 Tumor Suppressor Gene : Important Milestones at the Various Steps of Tumorigenesis. Genes Cancer $2: 466-474,2011$

10. Wu M, Mao C, Chen Q, Cu XW, Zhang WS : Serum p53 protein and anti-p53 antibodies are associated with increased cancer risk : a case-control study of 569 patients and 879 healthy controls. Mol Biol Rep $37: 339-343,2010$

11. Winter SF, Sekido Y, Minna JD, McIntire D, Johnson BE, Gazdar AF, Carbone DP : Antibodies against autologous tumor cell proteins in patients with small-cell lung cancer: association with improved survival. J Natl Cancer Inst 85 : 2012-2018, 1993

12. Angelopoulou K, Yu H, Bharaj B, Giai M, Diamandis EP : p53 gene mutation, tumor p53 protein overexpression, and serum p53 autoantibody generation in patients with breast cancer. Clin Biochem 33 : 53-62, 2000

13. Balogh GA, Mailo DA, Corte MM, Roncoroni P, Nardi H, Vincent E, Martinez D, Cafasso ME, Frizza A, Ponce G, Vincent E, Barutta E, Lizarraga P, Lizarraga G, Monti C, Paolillo E, Vincent R, Quatroquio R, Grimi C, Maturi H, Aimale M, Spinsanti C, Montero H, Santiago J, Shulman L, Rivadulla M, Machiavelli M, Salum G, Cuevas MA, Picolini J, Gentili A, Gentili R, Mordoh J : Mutant p53 protein in serum could be used as a molecular marker in human breast cancer. Int J Oncol 28 : 995-1002, 2006

14. Gao RJ, Bao HZ, Yang Q: The presence of serum anti-p53 antibodies from patients with invasive ductal carcinoma of breast : correlation to other clinical and biological parameters. Breast Cancer Res Treat $93: 111-115,2005$

15. Balogh GA, Mailo D, Nardi H, Corte MM, Vincent E, Barutta E, Lizarraga G, Lizarraga P, Montero H, Gentili R : Serological levels of mutated p53 protein are highly detected at early stages in breast cancer patients. Exp Ther Med 1:357-361, 2010

16. Kulić A, Sirotković-Skerlev M, Jelisavac-Cosić S, Herceg D, Kovac Z, Vrbanec D : Anti-p53 antibodies in serum : relationship to tumor biology and prognosis of breast cancer patients. Med Oncol $27:$ 887-893, 2010

17. Bao H, Yu D, Wang J, Qiu T, Yang J, Wang L: Predictive value of serum anti-p53 antibodies, carcino-embryonic antigen, carbohydrate antigen 15-3, estrogen receptor, progesterone receptor and human epidermal growth factor receptor-2 in taxane-based and anthracycline-based neoadjuvant chemotherapy in locally advanced breast cancer patients. Anticancer Drugs $19: 317-323,2008$

18. Yang Q, Mori I, Sakurai T, Yoshimura G, Suzuma T, Nakamura Y, Nakamura M, Taniguchi E, Tamaki T, Umemura T, Kakudo K : Correlation between nuclear grade and biological prognostic variables in invasive breast cancer. Breast Cancer 8: 105-110, 2001

19. Nozoe T, Mori E, Iguchi T, Egashira A, Adachi E, Matsukuma A, Ezaki T: Immunohistochemical expression of epidermal growth factor receptor in breast cancer. Breast Cancer 18 : 37 41,2011

20. de Ruijter TC, Veeck J, de Hoon JP, van Engeland M, TjanHeijnen VC : Characteristics of triple-negative breast cancer.J Cancer Res Clin Oncol 137 : 183-192, 2011 